\title{
Spiritual formation and the nurturing of creative spirituality: A case study in Proverbs
}

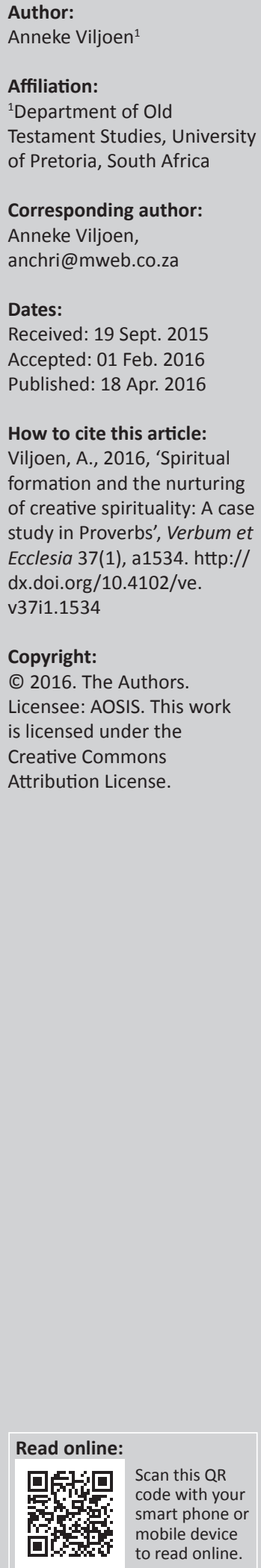

The article is positioned in the interface between Old Testament scholarship and the discipline of spiritual direction of which spiritual formation is a component. The contribution that a Ricoeurian hermeneutic may make in unlocking the potential which an imaginal engagement with the book of Proverbs may hold for the discipline of spiritual formation was explored. Specifically three aspects of the text of Proverbs illustrated the creative process at work in the text, and how it converges with the concept of spiritual formation and the nurturing of creative spirituality. These aspects were, the development in Lady Wisdom's discourses, the functional definition of the fear of Yahweh (illustrated from Proverbs 10:1-15:33), and the paradigmatic character of the book of Proverbs.

Intradisciplinary and/or interdisciplinary implications: The research is positioned in the interface between Old Testament studies and Practical Theology. The research results in the enhancement of the interdisciplinary dialogue and interchange of resources between the named disciplines with regard to the interest in formation of persons that the biblical book of Proverbs and the discipline of spiritual formation shares.

\section{Introduction}

A Ricoeurian hermeneutic presents a helpful tool for examining the process of spiritual formation. ${ }^{1}$ This is because Ricoeur is interested in the role of figurative texts in the formation of human subjectivity and understands religious studies to be a hermeneutical inquiry into the imaginative potential of myth, symbol, and story to aid our efforts to exist with integrity (Wallace 1995:14). ${ }^{2}$ In this article, the contribution that a Ricoeurian hermeneutic may make in terms of the simultaneous objective and subjective reference of the book of Proverbs is explored:

- The objective reference is to the symbolic textual world which Proverbs projects for its reader. This may aid the nurturing of creative spirituality.

- The subjective reference points to the reader's limit-experiences in and through this textual world, shaping his or her self-understanding. This may aid the discipline of spiritual formation. Thus, the article is positioned in the interface between Old Testament scholarship and the discipline of spiritual direction, of which spiritual formation is a component.

\section{Why the necessity?}

Willard (2000:254) notes that the spiritual formation of a person is inevitable and recommends that a conscious, intentional hand should be taken in this developmental process. He observes the need to think deeply and clearly about spiritual discipline and spiritual formation and their relationship to the deepest dimension of personality, that is, the human soul (Willard 1998:101). ${ }^{3}$ In the same vein, Conn (1999:87) regards spiritual formation and human formation to be inseparable without one being reduced to the other. In this regard, the understanding of the self or person in Proverbs and the book's distinctive focus on the formation of the person is highly relevant. I am of the opinion that the concern for the formation of the person in all of his or her facets or aspects is one that is shared by both secular society and religious communities. Concern for the formation of the person represents a point of convergence where these two spheres, which often function discretely, may enter into

1.i take spiritual formation, character formation, moral formation and psychological maturation to be aspects or facets of the same phenomenon, namely, (assistance in) the growth and maturation of the person. All these aspects or facets are inextricably bound together as Brown (1996), Conn (1999) and Lawrie (2013) point out. As I am a church pastor (of the Netherdutch Reformed Church of Africa's Pinetown congregation), my focus is on spiritual formation, but I am convinced that the principles are also applicable to character as well as moral formation and psychological maturation.

2.I have explored this aspect of Ricoeur's thought in relation to Proverbs in several articles (cf. Viljoen \& Venter 2013; Viljoen 2015a; Viljoen [No date, to be published]).

3. Hence, Beck (2003:25) concludes that the study of soul in the Old Testament is foundational to the competences we need to develop regarding spiritual formation and psychotherapy, and I may add, all disciplines concerned with the formation of the person.

Note: This aticle is an expanded version of a paper the author delivered at the ISBL conference in Buenos Aires, Argentina 20-24 July 2015. 
fruitful dialogue. When two public spheres share a common interest or concern, the resources which each possesses may be brought to the conversation to the mutual enrichment of both.

Akin to the separation between secular society and religious communities is the often disjointed relationship between academic scholarship and the Church. Although there seems to be a still widening chasm between academic scholarship and theological reflection, Brown (1996:1) notes that one thing unites both: 'an uncertainty over how to study and appropriate the wisdom literature of the Old Testament'. Kugel (2003:149) also notes the tendency of biblical scholarship to avoid studying Proverbs, especially in the light of what he calls its stark world view that is directly related to the spiritual aspect of the literature. ${ }^{4}$ I want to propose that the appropriation of wisdom literature ${ }^{5}$ (in general, and in this case, particularly Proverbs) in its interface with spiritual formation presents a prolific domain in which academic and ecclesiastical circles may draw closer to each other. The common interest I envision is for an adequate understanding of the person, and a concern for the formation of the total person.

Willard (1998:109) contends that an epistemic crisis marks the different professions. ${ }^{6}$ These professions are working in the dark because of a lack of understanding of what makes human life what it is. This crisis is a result of the modern context in which knowledge of the human self no longer fits the categories regarded as socially acceptable. He maintains that to develop accurate knowledge of the human self and an understanding thereof is the primary need of our time. If we accept this challenge we can begin to explore approaches that may be effective in the formation of persons (cf. Willard 1998:109, 2000:254). Willard (2000:254) maintains that understanding spiritual formation, and how it can best be done, is an indispensable aspect of developing a psychology that is adequate in regard to human life. He adds that no understanding of the human self can be theoretically or practically sufficient if it does not deal with the spiritual life (Willard 2000:256). I I believe that the convergence of Ricoeur's thoughts on the role of figurative texts in the formation of human subjectivity, together with the book of Proverbs' illocutionary force, may add some insight in this quest.

Unless we have at least some general idea of what is meant by the term 'spiritual formation' we will not know how to relate the content of the book of Proverbs and the concept of 'spiritual formation' where these two converge (cf. Turner 2013:188). Before these aspects are dealt with, however, two objections that may be raised against such an endeavour will first be briefly considered.

4.This failure is described by Kugel (2003:149) as a mistake and he stresses the need to think seriously about Proverbs' different way of seeing.

5.Lawrie (2013) calls for a practical approach to the study of wisdom literature when he laments: 'There are manifestly many theoretical studies of Old Testament wisdom. Others seem to have been written mainly so as to be marketable products conforming to accepted standards of craftsmanship. Very few, I fear, went beyond theoretical acumen and the requirements of the academic craft in their quest for the virtue of wisdom'.

6. He includes law and education, medicine and economics, even religion (Willard 1998:109).

7.Similarly, Van Huyssteen (2010) argues for a democratic presence of theology in the interdisciplinary, political, and cross-contextual conversation that constitutes public discourse, including the discourse in secular academic institutions.
The word 'spiritual' in the term 'spiritual formation' implies work with the non-physical part of the person. There are difficulties within the intellectual context that underlie the modern objections to working with the non-physical reality of the person. ${ }^{8}$ This is one of the objections to working with the idea of spiritual formation within the context of academic scholarship. Kugel (2003:162) notes that, since Descartes, the idea of soul(s) has generally been disdained in serious discourse. Conn (1999:87) alerts us to another objection that lies in the associations with the word 'formation'. There may be some resistance to the idea of spiritual formation within the context of academic scholarship as the idea may be perceived as a subtle manipulation of persons, or an attempt to form them according to an ideology. This is not what is generally meant by the term 'spiritual formation', and most certainly not what is meant here.

Willard's (2000:254-255) definition of 'spiritual formation' is a workable description of the concept which is useful. Turner (2013:188) explains that a range of partial synonyms, such as 'transformation', 'development', 'building up', 'maturation', 'sanctification', and the like, all signify what is meant by 'formation'. These words epitomise the process as being a dynamic and progressive one. Willard (2000) distinguishes three meanings for the term or concept 'spiritual formation' that point to three aspects of the dynamic process of spiritual formation. ${ }^{9}$ These three are interrelated aspects and coalesce to bring about the formation of the person:

- The first aspect points to certain specifically religious practices or activities identifying these as spiritual work or exercises. In this case, spiritual formation can be seen as training in these special spiritual activities. The goal is not just the shaping of overt behaviour, but goes beyond overt actions deeply into the inner or spiritual life of the person.

- Spiritual formation may also be thought of as the shaping of the inner life or the spiritual aspect of the person. Here, the focus is on what is formed, namely, manifestly the spiritual or non-physical dimension of the self. Spiritual formation in this case refers to the subject matter that has been shaped. The inner life expresses itself in external behaviour and it is assumed that through the process of spiritual formation there will be effects in the realm of overt practice.

- Spiritual formation may also refer to the shaping of the person by the spiritual realm. Within a manifestly Christian frame of reference the primary agent will be the Holy Spirit and other spiritual agencies involved in the Kingdom of God, including the Word of God.

Let us now turn to exploring the convergence of Ricoeur's thoughts on the role of figurative texts in the formation of human subjectivity and the illocutionary force of the text of Proverbs.

\section{In my opinion, Willard (1998:102) answers these objections sufficiently.}

9.Willard (2000:258) distinguishes between a general view of spiritual formation and a distinctly Christian spiritual formation. For him, Christian spiritual formation is centred on obedience to Christ operating from a transformed personality. He interprets the three aspects in a specifically Christian frame of reference: interprets the three aspects in a specifically Christian frame
1) Behaviour oriented towards explicit obedience to Christ

1) Behaviour oriented towards exciplines for life in the Spirit

2) Disciplines for life in the Spirit The movement of the Spirit through the agency of the Word of God transforms
the roots of behaviour throughout the whole person of the believer, soul and body, which goes beyond simply hearing and receiving this word. 


\section{Metaphoric bearing of the text of Proverbs}

'The proverbs belong to a basic wisdom genre that comes under the heading of the Hebrew term $m \bar{a} \bar{s} \bar{a} l^{\prime}$ (McKenzie 1996:3). The Hebrew word literary genre, but has a broad signification that is applied to a variety of forms and genres (Farmer 1991:17; Scott [1989] 1990:7). ${ }^{10}$ Mashal belongs to the connotative aspect of language and it uses non-literal language, speaking by indirection and suggestion to signify something else (Scott [1989] 1990:10).

In denotative language the expression is directly related to the content. Such is ordinary language ... In connotative language the expression and content themselves stand for an unnamed content, and for this very reason such language is suggestive, in need of interpretation. From the proverb or riddle's primary language the interpreter draws a signification not directly implied (Scott [1989] 1990:10-11).

Ricoeur sees poetic texts as having a metaphoric bearing. They point beyond themselves to something else. For Ricoeur, religious language is a unique and eccentric form of poetic language because it references God and indicates the limitpossibilities of the reader's life and self-understanding. Sandoval (2006:6) points out three aspects of Ricoeur's work on metaphor that are suggestive for studying the discourse in Proverbs. ${ }^{11}$ Firstly, Ricoeur offers a helpful model of how metaphors work. Secondly, Ricoeur suggests that a literary text opens up a view of a possible world that eclipses the tangible, objective world. ${ }^{12}$ Thirdly, he indicates how a text, which may not initially appear metaphorical, may reveal metaphorical characteristics. For the purposes of this article, the second and third aspects of Ricoeur's thoughts on metaphor in relation to the biblical book of Proverbs are considered here.

The working of the metaphorical process is essentially a creation of meaning and says something new about reality (Sandoval 2006:8). It is what Ricoeur calls a semantic innovation (Ricoeur 1975:79). Eco (1984) states:

As an ornament, the metaphor is of no interest to us, because, if it says more pleasantly that which can be said otherwise, then it could be explained wholly within the scope of a semantics of denotation. We are interested in the metaphor as an additive, not substitutive, instrument of knowledge. (p. 88)

The creative connotation is not limited to the level of only the sentence. On the level of the text, as a work of discourse, ' $[\mathrm{m}]$ etaphorical language is able to construct a new vision of reality' (Sandoval 2006:9). It has to do with the meaning of the

10.Longman (2006:21) notes that " $[i] \mathrm{n}$ the Septuagint the book is called paroimiai the Greek word used to translate $m \bar{a} s \bar{s} \bar{a} l$ in the first verse', and points out the strong correlation between this word and $\pi \alpha \rho \alpha \beta \rho \lambda \eta \dot{n}$, which can both refer to a wide variety of figurative language (see also Louw \& Nida 1996 sv 33.15; where $\pi \alpha \rho \alpha \beta \circ \lambda \eta ́$ and $\pi \alpha \rho \circ \mu \alpha^{\alpha} \alpha$ are discussed).

11.Sandoval (2006) applied this to a study of specifically the discourse of wealth and poverty in Proverbs.

12.This view can be said to correspond to the patterns of value and meaning that might be discerned in a particular discourse (Sandoval 2006:7). text as reference (Ricoeur 1976:19-22). Ricoeur distinguishes two levels of reference (Scott [1989] 1990:48). A first order reference is tied to a literal interpretation which is weakened and leads to a second order reference that suspends the literal level (Ricoeur 1975:84, cf. 1976 56-57; Sandoval 2006:9). A text may not only be describing reality in a literal, or empirically verifiable way, but may, through the literal meaning, come to a metaphorical meaning and actively be creating a symbolical world (Sandoval 2006:10). Thus, Ricoeur (1976:59) describes the poetic project as 'one of destroying the world as we ordinarily take it for granted' in order 'to bring to language modes of being that ordinary vision obscures or even represses' (Ricoeur 1976:60). Wallace (1995) understands it thus:

The aim of an imaginative text is the creative imitation of human action - even as the purpose of metaphor ... is to redescribe the actual world in terms of possibility. (p. 12)

The text constructs for the reader a symbolic-textual world (Sandoval 2006:10). In this way, a text has the ability to 'change one's view of, or relationship to, reality' (Sandoval 2006:9). 'By virtue of its power to fuse the world of the text and the world of the reader' (Wallace 2000:305), the text draws the reader into the world which the text unfolds in front of itself (Ricoeur 1977:23).

Sandoval (2006:6) affirms: 'Indeed the book of Proverbs constructs for its readers a complicated symbolic moral world'. He then goes on to explain the appropriateness and necessity of considering the book's figurative imagination, by pointing out that:

[f]eatures internal to various proverbial sayings along with the book's programmatic prologue and the form of its short sentence sayings all point to the figurative quality of key aspects of the text. (p. 6)

The context within which a proverb is performed commonly functions as a prompt or indicator that the proverb may, indeed should, be understood metaphorically (Sandoval 2006:11). It is generally recognised, not only by paremiologist scholars, but also by casual hearers or readers of proverbs, that they are by their regular usage - although they may make sense when taken literally - concerned to say something metaphorically about reality (Sandoval 2006:11). This may function as a cue that the text of Proverbs may be read with an eye towards its metaphorical bearing. This aspect will be developed later when the fear of Yahweh proverbs (in the collection Proverbs 10:1-15:33) are considered.

The fact of the collection and redaction of the book of Proverbs severed the proverbs from their original performance context that is crucial for understanding them (Sandoval 2006:12-13, 17; Schneider 1990:91). ${ }^{13}$ However, it was inserted into a new performance context, namely the textual context of the canonical book of Proverbs. This new performance context, together with the book's prologue (Proverbs 1:2-7) which

13.The proverbs in the Biblical book of Proverbs resemble and are related to folk-like proverbial sayings (Sandoval 2006:10), although they are the result of the creative process, including the collection and eventually redaction of the material by a scribal elite (Sandoval 2006:17, Whybray 1994:157-165; Ansberry 2010:1). 
'acts as a hermeneutical guide for the reader and provides a strong, initial literary cue for recognising the metaphorical aspects of the text' (Sandoval 2006:18), may function as yet another cue that the text of Proverbs may be read with an eye towards its metaphorical bearing. This aspect will be dealt with later when the development in Lady Wisdom's discourses is considered.

An extra-contextual cue that the text of Proverbs may be read with an eye towards its metaphorical bearing may be found in the 'extravagance', a 'mixing of the ordinary with the extra-ordinary, which serves as a sign of its metaphoricity' (Sandoval 2006:16). Sandoval (2006:16-17) considers the implication of this cue, which is augmented by Ricoeur's notion of tension in metaphorical statements, for the text of Proverbs. The extravagant claims of the act-consequence nexus in the book of Proverbs, with its assertion that the wise and righteous will prosper and the wicked perish, serves as a case in point. Sandoval (2006:16-17) points out that for Ricoeur there may be three levels of tension operative in a text:

- The tension between terms in a metaphor (i.e., between the tenor and the vehicle).

- The tension in interpretation that comes about when one attempts to understand a metaphorical utterance literally.

- A tension 'at the level of reality itself between description and redescription' (Ricoeur 1975:95), between 'the world the text figures and normal perceptions of the world of objects' (Sandoval 2006:17).

It may happen that little or no tension is to be perceived on the first two levels of a metaphorical discourse, that is, between the terms in the metaphorical utterance, or between a literal and metaphorical interpretation of an utterance. Then the extra-contextual cue to read the text with an eye towards its metaphorical bearing may be found in the tension between the reader's normal perception of the world of objects and the world which the text projects. This aspect will be developed further when the paradigmatic character of the book is considered.

From the discussion above, the metaphoric bearing of the text of Proverbs became clear. Next the convergence of the discipline of spiritual formation and the metaphoric bearing of the text of Proverbs will be considered.

\section{The convergence of the metaphoric bearing of the text of Proverbs with the discipline of spiritual formation}

According to Ricoeur (1975:107-145), religious language is a unique and eccentric form of poetic language, and not just one instance of it. In the words of Pellauer (1981:280), religious language 'adds something to the common traits of the poem'. It references God and indicates the limitpossibilities of the reader's life and self-understanding. It does this by both an objective as well as a subjective reference, simultaneously. It is herein that its specificity lies. Pellauer (1981:280) explains that objectively the reference is to another world - the world of the text and beyond it towards God; yet one that can become the reader's own world. Subjectively, it holds out the possibility of self-understanding to the reader it points to the reader's limit-experiences in, and through this textual world. Comprehending these two poles is the reference to God as a sort of convergence point which coordinates the whole (Pellauer 1981:280). Ricoeur (in Reese [1979] 1990:387) sees the text as mediating the reader's self-understanding: '.. it is the world of the text that "finally forms and transforms the self of the reader according to its intention"'. Hall (2006) describes it as follows:

To read the biblical texts is to participate in the redescription of reality initiated by the text and completed in the reader. What the texts offer to the imagination is, among other things, a moral redescription of reality. (p. 198)

Brueggemann (1993:18-25) understands the biblical text to be funding a counter-imagination of the world. 'What shows itself is in each instance a proposed world, a world I may inhabit and wherein I can project my ownmost possibilities' (Ricoeur 1977:25).

The self-understanding arising from the text with which Ricoeur is concerned (Reese [1979] 1990:387) coincides with the aim or illocutionary force of the biblical book of Proverbs. The appropriation of the text by the reader or 'mediation of the reader's self-understanding through the text' (Ricoeur in Reese [1979] 1990:387, author's italics) is the aim of Proverbs. Through formal or semantic features or a combination of both style and content, the proverb imposes itself on, and engages the reader (Clifford 2004:155). In this way a fusion between the world of the text and the world of the reader is initiated and the reader is invited to inhabit this symbolic-textual world as his or her own world. When this world is inhabited as his or her own world, that is, when the text is appropriated by the reader, the reader comes to a new self-understanding through the text and the text succeeds in its aim of forming and transforming the self of the reader. Several scholars observe that the simultaneous objective and subjective reference is at work within the book of Proverbs. ${ }^{14}$ The symbolic-textual world is a moral vision presented to the reader by the text that (re)constructs the reader's perception of reality and shapes his or her character (Ansberry 2011:125).

14.I also made reference to these scholars' observations in Viljoen and Venter (2013) In that article I focused on the objective reference of the text, whereas here I focus on the subjective reference of the text:

Ansberry (2011:125) concludes that 'Proverbs 10-24 incorporates aphorisms that reflect on the anthropocentric and theocentric dimensions of the world to offer fundamental moral vision that (re)constructs the addressee's perception of reality fundamental moral vision

From the prologue, Proverbs 1:2-6, Frydrych (2002:32-37) construes that the explicit intention of the book is to make a wise person out of the immature by vividly painting the consequences of wisdom and folly. He observes that various vividly painting the the various witnesses - the father, the grandfather, and even Wisdom herself - are brought in to testify to the benefits of wisdom and the shortcomings of folly. The book makes it clear to the reader, consequences of achoice between wisdom and folly. He continues. "Yet, as I have pointed out previously wisdom in Proverbs is not so much about knowing as about a commitment to a way of life, i.e., about doing through knowing' (Frydrych 2002:35)

Fox makes the same observation: 'In fact, wisdom is an art, not a science, and the sages of wisdom are artists - הכמים, as artists are called in Exod 36:4. The sages are artists painting a world whose realities often lie beneath the visible surface' (Fox 2007:684, author's italics). Cliford (2009:243) notes that the performance aspect (he the book "Prove" It does not provide factual data, its instructions are notably empty of "content," and its maxims can seem trite if one expects new data. Rather, Proverbs' sayings give readers a perspective'. 


\section{Discernment and commitment}

In the process of the (hermeneutical) appropriation of religious texts, Ricoeur's insistence that the specificity of religious language calls for discernment and commitment is important (Pellauer 1981:280; Reese [1979] 1990:395). This commitment is what opens the reader to the itineraries of meaning offered by the text in order to appropriate the text and apply it to his or her own life (Ricoeur 1981:14). Ricoeur (in Reese [1979] 1990:394) states that '[f]aith is the attitude of the one who is willing to be interpreted as he interprets the text-world'. Reese ([1979] 1990:394) comes to the conclusion that 'readers appropriate the text only by placing themselves before it in positive dialogue by letting the text play upon them'. The goal of the reader is to make the issue at stake in the text their own by opening themselves to the world it creates (Reese [1979] 1990:394). He continues: 'Such an interchange takes place within the context of faith; absolute trust in the authority of the text to create new possibilities' (Reese [1979] 1990:394). Here, both spiritual formation and the nurturing of a creative spirituality come into play. The reader of Proverbs reads it in the expectation of finding the creative process at work in the text. Through the act of reading, the reader participates in the creation of meaning and through the restructuring of his or her own world, in accordance with that of the text, also receives from this creative process a new understanding of himself or herself.

\section{Three aspects of the text of Proverbs that converge with the concept of spiritual formation}

There are three specific aspects of the text of Proverbs that may illustrate the creative process at work in the text and how it converges with the concept of spiritual formation.

\section{Development in Lady Wisdom's discourses}

The development in Lady Wisdom's discourses has to be considered against the backdrop of the canonical form of the book of Proverbs. ${ }^{15}$ The development in Lady Wisdom's discourses reveals a corresponding progressive development in her implied addressee (Brown 1996:37). ${ }^{16}$ There is a significant shift in the relationship between Lady Wisdom and her addressee which is apparent in how she addresses her hearer. Her initial discourse in Proverbs 1:22-33 is permeated with admonitions and reproof. The motivation strategy in this first discourse is notably a negative one. Here she gives a stern warning of what will happen if the addressee does not take

15.The book is the result of the creative process of collection and purposeful redaction of the material. Heim (2013:610-628) successfully points out that the phenomenon of variant repetition indicates an editorial concern that operates on the level of the book as a whole, encompassing the entire collection of collections. Thus, there is at least some evidence of the purposeful redaction of the material, though it might not be possible to formulate a single overarching theory of the redactional considerations.

16.The concern for loading the meaning of one individual proverb, lecture, interlude or collection with that from another is legitimate. Within the framework of my chosen reading strategy which focuses on the subjective reference of the text, 1 will, however, take the risk of reading the different discourses together. If one does not take that risk the text becomes so fragmented that it can no longer function as a purposefully redacted collection in its canonical form. It is in its canonical form a purposefully redacted collection in its canonical form. It is in its canon heed of her counsel. She vividly sketches in metaphorical terms the calamities that will befall the addressee as a result of non-adherence to her counsel and reproof. Terror will come like a storm and calamities like a whirlwind (Prov.1:27). Non-adherents to her counsel will have to eat the fruit of their way and have the fill of their own devices (Prov. 1:31). Even death and destruction await those who remain simple and complacent fools (Prov. 1:32).

Lady Wisdom's second discourse in Proverbs 8:4-36 is manifestly less negative than her first. In the first part of her discourse (Prov. 8:4-21) she outlines normative character. Her self-description is cast in the language of embodiment (Brown 1996:37). By the use of intense affective language she promulgates her traits in the hope that the reader will appropriate them (cf. Martin 2014). Her aim is to persuade the reader to desire her own character. She uses the allure of the metaphoric network of riches (fine gold, choice silver, and jewels in Prov. 8:10-11, 18-21) and honour (kings, princes, nobles, and rulers in Prov. 8:15-16, 18) in particular to coax the addressee into coveting her character traits and the subsequent behaviour that follows from such a character. Again she uses the metaphoric network of fruit and yield, although this time around in a positive association: 'My fruit is better than gold, even fine gold, and my yield than choice silver' (Prov. 8:19). In the following verses (Prov. 8:22-31) she erupts in a joyous reverie of her primordial position and joy in creation. This joy she holds out to the reader once again using affective language, this time of beatitudes. Reproof and negative motivation in the first discourse makes way for the positive motivation of the promise of joy and blessing in the second (cf. Brown 1996:38).

By the third discourse in Proverbs 9:4-6 Lady Wisdom acts as the hostess, inviting ${ }^{17}$ the reader to leave aside their simple ways and dine with her. Here the addressee has developed to such an extent that he or she may share in table community with Lady Wisdom. ${ }^{18}$ The exhortation to leave aside simple ways or immaturity is an invitation to embrace the maturity that comes with this table community. The metaphoric network of eating what is good is again played upon. The discourses have progressed from reproof through embodied instruction (in what desirable character may look like) to the addressee being invited to dine in table community with Lady Wisdom. The progression assumes and expresses the growth and formation of the reader which is the fundamental aim of the text of Proverbs.

\section{The fear of Yahweh in Proverbs 10:1-15:33 ${ }^{19}$}

The fear of Yahweh sayings, put together within their context, paint a picture for the reader which expresses Proverbs'

17.In verse 4 it is actually Lady Wisdom's young women who call, but they function as her emissaries, making the call of invitation on her behalf.

18.Brown (1996:38) notes the same progression in Jesus' discourse with the two disciples on the road to Emmaus (Luke 24:13), from rebuke to instruction to acting as host.

19.I use the occurrence of the fear of Yahweh-proverbs within the collection Proverbs 10:1-15:33 as a sample. The sample is sufficient to illustrate the creative process at work in the text of Proverbs (that is also at work in the other collections) and how it converges with the concept of the formation of the person. 
understanding of the fear of Yahweh. ${ }^{20}$ In this collection, the fear of Yahweh has a functional definition rather than an ontological one. The sayings are intended to persuade the reader to adhere to the fear of Yahweh. It vividly sketches how beneficially the fear of Yahweh functions in the life of a person who adheres to the sayings. The fear of Yahweh increases one's days, whereas it cuts short the years of the wicked (Prov. 10:27). It causes one to walk in uprightness, but a despiser of Yahweh walks in crookedness (Prov.14:2). It provides safety; one may find in it a trust of strength even for one's offspring (Prov. 14:26) and a source of life that keeps one far from the snares of death (Prov. 14:27). It provides peace, even in circumstances of meagre provisions and is of greater value than a great storehouse, especially when that is accompanied by trouble (Prov. 15:16). The fear of Yahweh, that is the instruction of wisdom leads through humility to the promise of honour (Prov. 15:33). In this way the fear of Yahweh is sketched in its beneficial function in the life of a person, in order to persuade the reader to adhere to it. The concept serves the formation of the person's interior motivation and attitudes as well as overt behaviour. Herein lies the book's strongest convergence with spiritual direction and formation.

\section{Paradigmatic character of Proverbs}

The language of the book of Proverbs is symbolic language which is 'the mother tongue of faith' (Aulén in Boström 1990:31). ${ }^{21}$ It is not a book characterised by theological reflection, intended to be read as an exhaustive systematic doctrine; rather it is a work of primarily theological-ethical nature (Boström 1990:31). Frydrych (2002:18-23) describes the proverbial project as functioning as a paradigm which is a tool of the practical mode of thought. ${ }^{22}$ He notes that 'the practical mode of thought' is other than 'the exact mode of thought', which has as its objective to describe the mechanics of a phenomenon fully (cf. Perdue 2000:33-35). ${ }^{23}$ In addition to the exact mode of thought, and in contrast to it, is the practical mode of thought, or practical knowledge which, for practical reasons under certain circumstances, settles for paradigmatic understanding or understanding that is only partial. At the heart of practical knowledge is a paradigm, ${ }^{24}$ that is, the depiction of the world the book of Proverbs offers is incomplete, but any possible shortcomings are

20.Whybray ([1979] 1990:158) works with the Yahweh-sayings in the collection Proverbs 15:33-16:9 emphasising that each of these are an individual entity and that a prosion progression of ideas cannot necessarily be observed within the collection. However, he notices the whoup of sayings 作 which Yahweh requires of them. His observation is most relevant to this study.
wition

21.As already mentioned, Sandoval (2006) also focuses attention on the figurative and rhetorical imagination of the text of Proverbs.

22.Van Huyssteen (2010:144) describes theological rationality as a pragmatic skill and on the basis of such an understanding of rationality he seeks to establish interdisciplinary dialogue.

23.To understand a given phenomenon, therefore, is, according to the exact mode of thought, 'to be able to describe fully the mechanics of it, to describe it as it really is' and is a concept of understanding frequently found in the exact sciences or a subject field such as dogmatics (Frydrych 2002:18, author's italics).

24.By a paradigm he means a theoretical system, which describes a behaviour of some other real system, and is used to predict the state of the real system on the basis of some input data. The paradigm or theoretical system, however, is always simpler than the real system. considered of only limited significance under the specific circumstances.

The book offers understanding with a practical end in mind, and the value of this understanding is in its practical application:

The paradigm is constructed as a kaleidoscope, where the whole image of the world is constructed by a combination of the glimpses that the individual proverbs offer, and is more than a simple sum of the parts. (Frydrych 2002:43; cf. Edmondson 2005:342; Murphy 1998:xxvi)

Thus, what is presented in Proverbs is not intended to be understood as a product of the exact mode of thought and is thus not meant to be exhaustive. ${ }^{25}$ The necessary corollary is that individual proverbs have to be read together in order to get a fuller picture of the sage's thinking or understanding.

This brings the next observation to the fore. The antithetical structure of many of the proverbs is a literary expression of the understanding of the structure of the symbolic-textual world that is sketched by the proverbs (cf. Loader 1986:107-110). Proverbs demonstrates an understanding of the human world as bifurcated into the righteous-wise on the one hand, and the wicked-fools, on the other (Ansberry 2010:162). These are in antithetical opposition to each other and for Proverbs there is no other category. Kugel (2003:137-168) describes this way of looking at the world in terms of starkness, an almost blackand-white view of reality, a world of absolute polarities with no middle ground. ${ }^{2} 6$

This bifurcated understanding of reality could easily be perceived as restrictive and stereotyped. The fact that Proverbs makes little room for alternative categories can even be offending to modern-day readers who generally regard reality as much more complex than is allowed for by such an uncomplicated division (Kugel 2003:145; cf. Obelkevich in Hildebrandt 2005:59). However, when the paradigmatic character of Proverbs, together with the aim (or illocutionary force) of the text is taken into account, it is to be expected that the symbolic-textual world should be sketched in this way. The view of reality in Proverbs is a most effective supporting apparatus in the formation of the reader's character. The symbolic-textual world of Proverbs confronts the reader with the question of her or his own position in terms of this world view in order to come to a new self-understanding. ${ }^{27}$ This process is, however, not

25. In addition to this, the literary form of the proverbs adds to the paradigmatic fee of the text. The proverbs are limited by the characteristics of brevity and catchiness, and as Parsons (1993:159) notes, on the surface some proverbs read almost like an algebraic equation or mechanical law. However, he cites Fee and Stuart's apt observation that proverbs are worded to be memorable rather than technically precise. Thus, the very nature of their literary form necessitates that the proverbs in some instances overstate the case and oversimplify without including fine print or footnotes with lists of exceptions (Parsons 1993:159; cf. Murphy 1998:xxv-xxvi).

26. He calls it a different kind of realism that has to do with perception, how the reader is to perceive the world (Kugel 2003:156).

27.This is especially evident in Proverbs 14:2 where the descriptive nature of the proverb seems simply to be making an observation. However, Hildebrand $(1992: 436)$ notes that a naive reading of the sentences in Proverbs $10-15$ (e.g.
$10: 1,4,5)$ reveals that many of the sentences go beyond mere empirical $10: 1,4,5)$ reveals that many of the senter
observation to being motivationally directive. 
an automatic response to the text but develops within the atmosphere of a creative spirituality that needs to be nurtured. The appositeness of the proverbial perspective is highlighted within the context of spiritual formation.

\section{Conclusion}

A Ricoeurian hermeneutic presents a helpful apparatus for the process of spiritual formation. This is because Ricoeur is interested in the role of figurative texts in the formation of human subjectivity. For Ricoeur, religious language is a unique and eccentric form of poetic language because it references God and indicates the limit-possibilities of the reader's life and self-understanding. It does this by both an objective as well as a subjective reference, simultaneously. Objectively, the reference is to another world - the world of the text - yet one that can become the reader's own world. Subjectively, it holds out the possibility of self-understanding to the reader - it points to the reader's limit-experiences, in and through this referenced world. Ricoeur's insistence that the specificity of religious language calls for discernment and commitment may aid the nurturing of a creative spirituality. This commitment opens the reader to the itineraries of meaning offered by the text in order to appropriate the text and apply it to his or her own life. The goal of the reader is to make the issue at stake in the text his or her own by opening himself or herself to the world it creates (Viljoen 2015b).

Several scholars have observed the simultaneous objective and subjective references at work within the book of Proverbs. The self-understanding arising from the text in which Ricoeur is interested coincides with the aim or illocutionary force of the text of Proverbs. The symbolic-textual world of Proverbs is a moral vision presented to the reader by the text that (re) constructs the reader's perception of reality and shapes his or her character (Viljoen 2015b). This was illustrated with reference to three specific aspects of the text of Proverbs which demonstrate the creative process at work in the text and how it converges with the concept of spiritual formation. These were, the development in Lady Wisdom's discourses, the functional definition of the fear of Yahweh (illustrated from Proverbs 10:1-15:33), and the paradigmatic character of the book of Proverbs.

\section{Acknowledgements Competing interests}

The author declares that she has no financial or personal relationships which may have inappropriately influenced her in writing this article.

\section{References}

Ansberry, C.B., 2010, 'What does Jerusalem have to do with Athens?: The moral vision of the book of Proverbs and Aristotle's Nicomachean ethics', Hebrew Studies 51, 157-173.

Ansberry, C.B., 2011, Be wise my son, and make my heart glad: An exploration of the courtly nature of the book of Proverbs, De Gruyter, Berlin.

Beck, J.R., 2003, 'Self and soul: Exploring the boundary between psychotherapy and spiritual formation', Journal of Psychology and Theology 31(1), 24-36.
Boström, L., 1990, The God of the sages: The portrayal of God in the book of Proverbs, Almqvist \& Wiksell International, Stockholm.

Brown, W.P., 1996, Character in crisis: A fresh approach to the wisdom literature of the Old Testament, Eerdmans Publishing Company, Grand Rapids, MI.

Brueggemann, W., 1993, The Bible and postmodern imagination: Texts under negotiation, SCM Press, London.

Clifford, R.J., 2004, 'Your attention please! Heeding the proverbs', Journal for the Study of the Old Testament 29(2), 155-163.

Clifford, R.J., 2009, 'Reading Proverbs 10-22', Interpretation 63, viewed 08 June 2012, from http://int.sagepub.com/content/63/3/242

Conn, J.W., 1999, 'Spiritual formation', Theology Today 56(1), 86-97.

Eco, U., 1984, Semiotics and the philosophy of language, Indiana University Press, Bloomingdon, IN, viewed 06 March 2012, from http://0-books.google.co.za. innopac.up.ac.za/books?hl=en\&lr=\&id=aqTkkHZsIMwC\&oi=fnd\&pg=PR9\&dq=ec innopac.up.ac. $z a /$ books? $h=e n \&|r=\& i d=a q T k k H Z s| M w C \& O i=f n d \& p g=P R 9 \& d q=e c$
o+semiotics $\&$ ots $=9 g S g V d R m Q i \& s i g=T g 6 Y 2 r v 6 Q B H-k q E y Z Q 0 Q v g y f 6 j 4 \# v=$ onepage \& $q=e$ eco\%20miotics\& $f=$ false

Edmondson, R., 2005, 'Wisdom in later life: Ethnographic approaches', Ageing and Society 25(6), 339-356.

Farmer, K.A., 1991, Who knows what is good: A commentary on the books of Proverbs and Ecclesiastes, Eerdmans, Grand Rapids, MI.

Fox, M.V., 2007, 'The epistemology of the book of Proverbs', Journal of Biblical Literature 126(4), 669-684.

Frydrych, T., 2002, Living under the sun: Examination of Proverbs and Coheleth, Volume 90 , Brill, Leiden.

Hall, D.W., 2006, 'The economy of the gift: Paul Ricoeur's poetic redescription of reality', Literature \& Theology 20(2), 189-204.

Heim, K.M., 2013, Poetic imagination in Proverbs: Variant repetitions and the nature of poetry, Eisenbrauns, Winona Lake.

Hildebrandt, T., 1992, 'Motivation and antithetic parallelism in Proverbs 10-15', Journal of the Evangelical Theological Society 35(4), 433-444.

Hildebrandt, T., 2005, The proverb: An interdisciplinary approach to a Biblical genre, viewed 13 November 2012, from http://0-faculty.gordon.edu.innopac.up.ac.za/ hu/bi/Ted_Hildebrandt/OTeSources/20-Proverbs/Text/Articles/Hildebrandthu/bi/Ted_Hildebrandt/ot
Proverb-Genre-2005.pdf

Kugel, J.L., 2003, The God of old: Inside the lost world of the Bible, Free Press, New York.

Lawrie, D., 2013, 'Old ideas: Wisdom, virtue and moral formation', Scriptura 112(1), $1-15$.

Loader, J.A., 1986, 'Tekste met 'n wysheidsperspektief', in F.E. Deist \& W.S. Vorster (eds.), Woorde wat ver kom, pp. 103-122, Tafelberg Publishers, Cape Town.

Longman, T., 2006, Proverbs (Baker commentary on the Old Testament wisdom and Psalms), Baker Academic, Grand Rapids, MI.

Louw, J. P. \& Nida, E.A., 1996, Greek-English lexicon of the New Testament: based on semantic domains, electronic ed. of the 2nd edn., United Bible Societies, New York, NY.

Martin, L.M., 2014, 'Rhetorical criticism and the affective dimension of the biblical text', Journal for Semitics 23/2i, 339-353.

McKenzie, A.M., 1996, Preaching Proverbs: Wisdom for the pulpit, Westminster John Knox Press, Louisville, KY.

Murphy, R.E., 1998, Proverbs (Word Biblical Commentary Volume 22), Thomas Nelson Inc, Nashville, TN.

Parsons, G.W., 1993, 'Guidelines for understanding and proclaiming the book of Proverbs', Bibliotheca Sacra 150, 151-170.

Pellauer, D., 1981, 'Paul Ricoeur on the Specificity of Religious Language', The Journa of Religion 61(3), 264-284.

Perdue, L.G., 2000, Proverbs (Interpretation: A Bible commentary for teaching and preaching), John Knox Press, Louisville, KY.

Reese, J.M., [1979] 1990, 'Can Paul Ricoeur's method contribute to interpreting the book of Wisdom?', in M. Gilbert (ed.), La sagesse de l'Ancien Testament, pp. 384-396, Leuven University Press, Leuven.

Ricoeur, P., 1975, 'Biblical Hermeneutics', Semeia 4, 29-148.

Ricoeur, P., 1976, Interpretation theory: Discourse and the surplus of meaning, Texas Christian University Press, Fort Worth, TX.

Ricoeur, P., 1977, 'Toward a Hermeneutic of the Idea of Revelation', Harvard Theological Review 70, 1-37.

Ricoeur, P., 1981, 'The Bible and the imagination', in H.D. Betz, (ed.), The Bible as a document of the university, pp. 1-20, Scholars Press, California, viewed 28 February 2012, from http://www.fondsricoeur.fr/photo/Ricoeur\%20\%20The\%20 Bible\%20and\%20the\%20lmagination.pdf

Sandoval, T.J., 2006, The discourse of wealth and poverty in the book of Proverbs, Brill, Leiden.

Schneider, T.R., 1990, 'The sharpening of wisdom: Old Testament proverbs in translation', D.Th-thesis, University of South Africa.

Scott, B.B., [1989] 1990, Hear then the parables: A commentary on the parables of Jesus, Fortress Press, Minneapolis, MN.

Turner, M., 2013, 'Spiritual gifts and spiritual formation in I Corinthians and Ephesians', Journal of Pentecostal Theology 22, 187-205. 
Van Huyssteen, J.W., 2010, 'What makes us human? The interdisciplinary challenge to theological anthropology and Christology', Toronto Journal of Theology 26(2), 143-160.

Viljoen, A., 2015a, 'The structuring considerations of a Ricoeurian hermeneutic employed in a reading of Proverbs 14:2', HTS Teologiese Studies/Theological Studies 71(3), Art. \#2849, 7 pages. http://dx.doi.org/10.4102/hts.v71i3.2849

Viljoen, A., 2015b, 'Spiritual Formation and the Nurturing of Creative Spirituality: A Case Study in Proverbs', paper presented at the ISBL conference, Buenos Aires, Argentina, 20-24, viewed n.d., from http://www.sbl-site.org/meetings/Congresses_Abstracts. aspx? Meetingld $=26$

Viljoen, A., in press, 'Imagination as hermeneutical device: Exploring the hermeneutical contribution of an imaginal engagement with the text'.

Viljoen, A. \& Venter, P.M., 2013, 'An exploration of the symbolic world of Proverbs 10:1-15:33 with specific reference to "the fear of the Lord"', HTS Teologiese Studies/Theological Studies 69(1), Art. \#2008, 6 pages. http://dx.doi.org/10.4102/ hts.v69i1.2008
Wallace, M.I., 1995, 'Introduction', in Figuring the sacred: Religion, narrative and imagination, D. Pellauer (trans), M.I. Wallace (ed.), pp. 1-35, Fortress, Minneapolis, MN.

Wallace, M.I., 2000, 'From phenomenology to Scripture? Paul Ricoeur's hermeneutical philosophy of religion', Modern Theology 16(3), 301-313.

Whybray, R.N., [1979] 1990, 'Yahweh-sayings and their context in Proverbs 10, 1-22,16', in M. Gilbert (ed.), La sagesse de l'Ancien Testament, pp. 153-165, Leuven University Press, Leuven.

Whybray, R.N., 1994, The composition of the book of Proverbs Journal for the Study of the Old Testament Supplement, 168, JSOT Press, Sheffield.

Willard, D., 1998, 'Spiritual disciplines, spiritual formation and the restoration of the soul', Journal of Psychology and Theology 26(1), 101-109.

Willard, D., 2000, 'Spiritual formation in Christ: A perspective on what it is and how it might be done', Journal of Psychology and Theology 28(4), 254-258. 